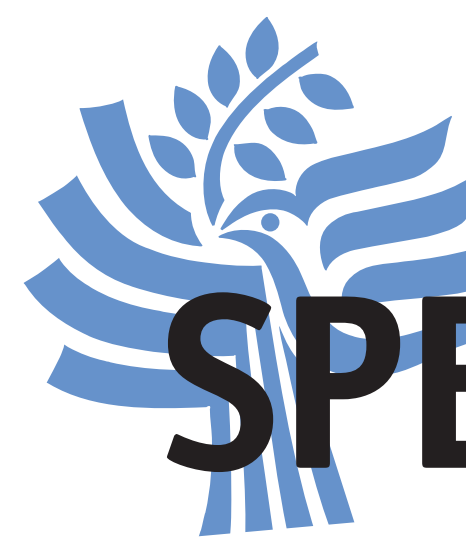

ABOUT THE REPORT

This report informs the international community on the challenges to investigating and prosecuting peacekeepers who sexually exploit and abuse the civilians they are meant to protect.

ABOUt THE AUthor Carla Ferstman is director of REDRESS, a London-based human rights organization that helps torture survivors obtain justice and reparation, and was a Jennings Randolph senior fellow at USIP (2012-13). She previously served as REDRESS's legal director and as the executive legal adviser of the Commission for Real Property Claims in Bosnia and Herzegovina, a mass claims body established under the Dayton Peace Agreement. Earlier, she served with the UN in Rwanda and with Amnesty International on an initiative on trials in the Great Lakes region of Africa. The author is grateful to Jenee Sharon for research assistance and to colleagues at USIP for fruitful exchanges on the topic.

๑ 2013 by the United States Institute of Peace. All rights reserved.

Special Report 335 SEPTEMBER 2013

CONTENTS

Exploitation and Abuse 2 Criminal Accountability 3 Obligations of Troop-Contributing Countries 4 Host State Role 6 Recommendations 11
UNITED STATES INSTITUTE OF PEACE www.usip.org

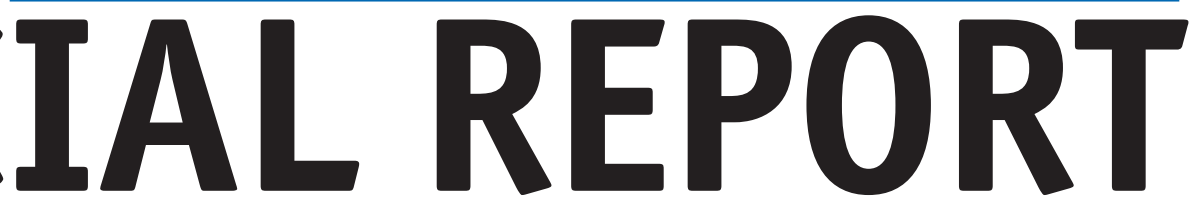

2301 Constitution Ave., NW • Washington, DC $20037 \bullet 202.457 .1700 \bullet$ fax 202.429.6063

\author{
Carla Ferstman
}

Criminalizing Sexual Exploitation and Abuse by Peacekeepers

\section{Summary}

- Sexual exploitation and abuse continue to pervade peacekeeping missions, and peacekeepers benefit from near-total impunity.

- Several seminal United Nations (UN) studies and expert reports provide a useful blueprint of where the gaps lie, what must be done to address them, and how to do so.

- Zero-tolerance UN policies have focused on preventing new abuse and strengthening codes of conduct. These goals are laudable but undermined when not accompanied by consistent discipline and criminal accountability.

- Despite eight years of annual resolutions that underscore the need to address the problems, there is no evidence of greater accountability.

- More work is needed to finish the job. States are responsible for disciplining and punishing their troops, but the UN must do more to ensure that this happens.

- The UN needs to work actively with states to bridge the gaps in domestic legislation by issuing written advice and publishing model legislation.

- The UN should publicly name and shame those states that fail to investigate and prosecute credible cases.

- The UN should refrain from accepting troop contingents from countries that repeatedly fail to live up to their written assurances to investigate and prosecute.

- The memorandum of understanding governing the relationship between the UN and troop-contributing countries should be further revised to introduce greater conditionality into the acceptance and removal of troop contingents. 


\section{ABOUT THE INSTTUTE}

The United States Institute of Peace is an independent, nonpartisan institution established and funded by Congress.

Its goals are to help prevent and resolve violent conflicts, promote post-conflict peacebuilding, and increase conflict management tools, capacity, and intellectual capital worldwide. The Institute does this by empowering others with knowledge, skills, and resources, as well as by its direct involvement in conflict zones around the globe.

BOARD OF DiRECTORS

J. Robinson West (Chair), Chairman, PFC Energy, Washington, DC • George E. Moose (Vice Chair), Adjunct Professor of Practice, The George Washington University, Washington, DC • Judy Ansley, Former Assistant to the President and Deputy National Security Advisor under George W. Bush, Washington, DC • Eric Edelman, Hertog Distinguished Practitioner in Residence, Johns Hopkins School of Advanced International Studies, Washington, DC

- Joseph Eldridge, University Chaplain and Senior Adjunct Professorial Lecturer, School of International Service, American University, Washington, DC • Stephen J. Hadley, Principal, RiceHadleyGates, LLC, Washington, DC ・ Kerry Kennedy, President, Robert F. Kennedy Center for Justice and Human Rights, Washington, DC $\bullet$ Ikram U. Khan,

President, Quality Care Consultants, LLC., Las Vegas, NV •

Stephen D. Krasner, Graham H. Stuart Professor of International Relations at Stanford University, Palo Alto, CA

- John A. Lancaster, Former Executive Director, International Council on Independent Living, Potsdam, NY • Jeremy A. Rabkin, Professor of Law, George Mason University, Fairfax, VA • Judy Van Rest, Executive Vice President, International Republican Institute, Washington, DC • Nancy Zirkin, Executive Vice President, Leadership Conference on Civil and Human Rights, Washington, DC

Members EX OfFICIO John Kerry, Secretary of State $\bullet$ Kathleen Hicks, Principal Deputy Under Secretary of Defense for Policy $\bullet$ Gregg F.

Martin, Major General, U.S. Army; President, National Defense University • Jim Marshall, President, United States Institute of Peace (nonvoting)

The views expressed in this report do not necessarily reflect the views of the United States Institute of Peace, which does not advocate specific policy positions.

To request permission to photocopy or reprint materials, e-mail: permissions@usip.org

\section{Exploitation and Abuse}

Despite peacekeepers' enormous contributions to and sacrifices for the cause of peace and security, they have increasingly been associated with sexual exploitation and abuse of the vulnerable populations they are mandated to protect. Tragically, they benefit from neartotal impunity. It is a reality that the presence of peacekeepers in countries with precarious legal and social structures can foster sexual exploitation and abuse.

In countries as diverse as Angola, Bosnia and Herzegovina, Cambodia, Democratic Republic of the Congo (DRC), East Timor, Eritrea, Kosovo, Liberia, Mozambique, Sierra Leone, and Somalia, numerous examples of rape, pedophilia, prostitution, and other forms of sexual exploitation and abuse have come to light in recent decades. ${ }^{1}$ The effect of such abuses is stark. Not only is it a direct one for the most vulnerable segments of society, its ramifications for the reputation of peacekeeping initiatives and the UN generally are also extremely wide, potentially impeding the organization from successfully carrying out other aspects of its mission. ${ }^{2}$

Peacekeepers are mandated to protect civilian populations and indeed to prevent the heinous acts of mass sexual violence that have become synonymous with many modern-day conflicts. This responsibility is the ethos of their mission. ${ }^{3}$ In June 2013, the UN Security Council adopted a resolution on women, peace, and security in which it requests "the Secretary-General to continue and strengthen efforts to implement the policy of zero tolerance on sexual exploitation and abuse by UN personnel and urges concerned Member States to ensure full accountability, including prosecutions, in cases of such conduct involving their nationals." ${ }^{\text {"4 }}$ This resolution is preceded by numerous others making nearly identical requests. Seminal reports by experts have been commissioned and revised memorandums that afford the UN much stronger powers of oversight have been signed, yet years after a series of comprehensive strategies were recommended in 2006, little appears to have changed: accountability remains the exception to the rule, new abuses continue to be reported, and the business of sexual exploitation and abuse in peacekeeping continues. The inevitable result of complacency and unimplemented strategies is impunity among peacekeepers.

This impunity can be construed as a symbol for double standards. In 2011, the UN secretary-general adopted a human rights due diligence policy that requires all security sector support provided by the UN to be consistent with its obligations to respect, promote, and encourage respect for international humanitarian, human rights, and refugee law. The policy reflects the need for the UN not to be associated with such abuses. However, if the UN imposes conditions on its collaboration with local government troops, is it not just as important that the UN's contingents are free of the stain of abuse, particularly sexual violence? In 2013, allegations of mass rapes allegedly perpetrated by certain government troops in the DRC reportedly led the UN to review parts of its security sector support in the country. Yet at the same time, the scores of sexual exploitation and abuse allegations levied against UN troops in the DRC have remained unanswered and unpunished since the early 2000s. These inconsistent standards send mixed messages and undermine the broader significance of zero tolerance for sexual violence.

This report considers the myriad steps taken by the UN and its member states to address the problem of sexual exploitation and abuse by peacekeepers. In particular, it assesses the efforts taken to increase criminal accountability. Significant barriers continue to impede criminal investigations and prosecutions of peacekeepers and other personnel for crimes related to sexual exploitation and abuse.

Given the UN's lack of competence over disciplinary and criminal matters, and the absence of an appropriate international criminal tribunal to prosecute crimes associated with sexual exploitation and abuse, focus has turned to national investigations and prosecutions, which is 
appropriate. ${ }^{5}$ Both would normally be undertaken by the troop-contributing countries. In light of the limited success with such prosecutions to date, however, a number of expert studies have also recommended, somewhat controversially, that greater attention should be paid to the possibility for the host state-the state emerging from conflict where the peacekeepers are stationed and where the crimes are understood to have taken place-and possibly other states as well to carry out complementary investigations and prosecutions.

This report canvasses what has been proposed and what steps have been taken and argues that, despite the progress, much more needs to be done if accountability is to be assured. The barriers to investigations and prosecutions are known; the options to remedy them have been meticulously set out in a series of reports. Nevertheless, significant gaps remain. The failure to routinely prosecute and punish abusers undermines other laudable prevention efforts and makes a mockery of the victims and all that they have endured. Addressing the criminal law barriers is thus a necessary component of any strategy to eradicate sexual exploitation and abuse in peacekeeping missions. It remains a pressing concern.

In March 2013, the UN's Office of Internal Oversight Services (OIOS) released its latest annual report, in which it revealed that sexual exploitation and abuse remains a significant problem in peacekeeping missions. ${ }^{6}$ The reported number of fresh allegations has dropped from the peak seen in the early 2000s, which is a positive indication that preventive measures are slowly working. ${ }^{7}$ However, the figures still remain unacceptably high even without taking underreporting into account. ${ }^{8}$ In 2012, sixty fresh allegations were reported in ten field missions. ${ }^{9}$ Significantly, the rate of related criminal prosecutions remains negligible.

The notorious incidents from the late 1990s and early 2000s propelled a series of initiatives aimed at tackling the problem. In 2005, Prince Zeid Ra'ad Zeid Al-Hussein's landmark study drew much-needed attention to the problem of sexual exploitation and abuse on missions and recommended remedial measures. ${ }^{10}$ Many of the recommendations have since been implemented. In particular, standards of conduct have been clarified for all troops, ${ }^{11}$ the model memorandum of understanding that regulates the relationship between troopcontributing countries and the UN was amended, ${ }^{12}$ and a special prevention task force has been created. ${ }^{13}$ Protocols for assistance and support to victims have been issued. ${ }^{14}$ Outreach, mandatory training, and other broader measures of prevention have been standardized across peacekeeping missions. ${ }^{15}$ In addition, an arm's length administrative investigation structure has been put in place. ${ }^{16}$

Yet the Zeid report also drew attention to the need for greater and more consistent recourse to disciplinary and criminal action, and it is these measures that have proved to be most difficult to implement.

\section{Criminal Accountability}

The difficulties in investigating sexual violence allegations are well documented. Indeed, experience from international criminal tribunals and courts underscores the fact that unless both a well-defined operational strategy and investigators specially trained in the investigation of such crimes are in place, evidence of a sufficiently high quality is unlikely to be available. ${ }^{17}$ The stigma, fear, trauma, and isolation engendered by such crimes require special investigation strategies. This need is especially pronounced when both the suspects and the investigators are foreign. Nonetheless, the challenges to properly and adequately investigate sexual exploitation and abuse cases will exist regardless of the perpetrators and the nationality of the investigators. These challenges, coupled with the general lack of interest in rigorous investigation, make it unsurprising that many of the allegations are not known to have resulted in criminal prosecutions.

\section{In 2012, sixty fresh allegations were reported in ten field missions. ... The rate of related criminal prosecutions remains negligible.}




\section{Gaps or loopholes may prevent certain categories of persons or certain types of offenses from being prosecuted.}

According to the UN Model Status of Forces Agreement, troop-contributing countries have the exclusive responsibility to discipline and criminally sanction their military contingents. ${ }^{18}$ Even for other types of personnel for whom the troop-contributing country does not have exclusive jurisdiction, the overwhelming practice has been for the UN to refer the case to the troop-contributing country anyway. ${ }^{19}$ When allegations of serious misconduct are made, the UN can repatriate the individuals concerned, make recommendations to the troop-contributing country, and ban the individual from future peacekeeping operations. When suspects are returned to the troop-contributing country, contingents can and should be subject to that state's criminal and disciplinary jurisdiction. However, as Françoise Hampson has noted, holding such trials entails certain practical difficulties, including accessing evidence in the host state. Local laws also will not always allow for extraterritorial prosecutions. ${ }^{20}$ Finally, gaps or loopholes may prevent certain categories of persons or certain types of offenses from being prosecuted. 21 Thus, when the troopcontributing country fails to act for any of those reasons, the result is impunity.

Information on troop-contributing country investigations and prosecutions is patchy and available primarily through anecdotal public news reports. This is largely because the UN Department of Field Support's Conduct and Discipline Unit has published only generalized statistics, not information on completed prosecutions per troop-contributing country. The statistics note the aggregate number of responses the Conduct and Discipline Unit has received to its queries but not which states have responded or the nature or adequacy of the responses. ${ }^{22}$ The media have focused only on particularly notorious or well-publicized incidents. Recently, a Pakistani court martial operating in Haiti reportedly found several Pakistani police officers guilty of sexual exploitation and abuse, but this case appears to be more an exception than the rule. ${ }^{23}$ Numerous credible allegations have not resulted in prosecution. For example, preliminary information implicating fourteen Moroccan troops serving in Côte d'Tvoire-including DNA evidence showing that some had fathered children-reportedly did not result in conclusive evidence and led the Moroccan government to drop all charges. ${ }^{24}$ Multiple allegations against Indian peacekeepers for being involved in a child prostitution ring in the DRC are likewise not known to have resulted in prosecutions. ${ }^{25}$ In a relatively recent case involving allegations that Uruguayan peacekeepers sexually abused a teenage boy in Haiti, the media coverage led the Uruguayan president to issue an apology. Nevertheless, apparently because of the paucity of evidence-despite the existence of video footage - the accused soldiers have not been charged with sexual violence but with much lesser "coercion" offenses. ${ }^{26}$

The successful prosecution of sexual exploitation and abuse allegations requires expertise at the outset to determine how best evidence can be collected and used. It requires particular expertise in working with witnesses who have a history of marginalization, have experienced significant trauma, face severe cultural taboos when coming forward to give evidence, or fear reprisals. Such expertise is available within the UN system from the ad hoc international criminal tribunals, though not always available among domestic military prosecutors, whether these come from a troop-contributing country or a host state.

\section{Obligations of Troop-Contributing Countries}

The model memorandum of understanding that regulates the relationship between troopcontributing countries and the UN was amended in 2007 in response to the recommendations of the Zeid report. ${ }^{27}$ It now provides clearer emphasis on to the need to ensure criminal responsibility for acts of sexual abuse and exploitation carried out by national contingents of troop-contributing countries on peacekeeping missions. This effort has been accomplished by providing assurances, information sharing, authorizing the UN to carry out initial investigations, and vetting candidates before deployment. 
- Providing assurances. Troop-contributing countries are now required "to assure the United Nations that it shall exercise such jurisdiction with respect to such crimes or offences,"28 and that "the case is forwarded to its appropriate authorities for due action" by authorities who "shall take their decision in the same manner as they would in respect of any other offence or disciplinary infraction of a similar nature under its laws or relevant disciplinary code." 29 However, this assurance cannot be legally enforced, though it carries moral weight and sets the stage for the UN to engage in a dialogue with states on the concrete steps they have taken to provide the assurance.

- Information sharing. The troop-contributing country is now obligated to "notify the Secretary-General of progress on a regular basis, including the outcome of the case." 30 This step is a significant advance. In 2005, Hampson noted that

there is evidence of a lack of follow-up. Apparently at least 90 percent of repatriated CIVPOL [civilian police] officers' cases are not followed up by the United Nations. Part of the problem is that there is no obligation on the sending State to supply information with regard to disciplinary/criminal proceedings against repatriated officers. Another possible difficulty is the administrative burden that might be imposed by effective follow-up. ${ }^{31}$

That troop-contributing countries are now obliged to report to the UN on the progress and outcome of misconduct investigations and prosecutions is therefore an important improvement. ${ }^{32}$ However, not all states have responded to requests for information. The 2012 statistics hover around a 50 percent response rate. ${ }^{33}$ This is much higher than in previous years but much lower than it should be. Each allegation merits a response. Furthermore, the responses factored into the 50 percent statistic are not necessarily full and complete disclosure: Responses may entail only acknowledgment of receipt and an indication of what further steps are envisioned.

The UN only makes public the aggregated statistics and refrains from naming and shaming particular countries. Although this is understandable from the perspective that the UN relies on the continued support of troop-contributing countries and does not wish to risk hurting those relationships, the policy also reduces the importance and strength of the information-sharing exercise. If the countries concerned do not risk public shame, incentive for compliance is reduced.

- Authorizing the UN to investigate. The UN will typically have some role in the preliminary administrative investigation of allegations. It may be the first to hear the allegations. Even when it does, if the troop-contributing country has exclusive jurisdiction, the allegation will need to be processed and transferred to that country. Per the new obligation to share information, however, the UN should also receive, process, and catalogue all information from troopcontributing countries. The revised memorandum entitles the UN to carry out preliminary fact-finding investigations in cases of serious misconduct if necessary to preserve evidence and when the troop-contributing country does not conduct its own. ${ }^{34}$ The UN's Investigations Unit of the OIOS is also authorized to initiate an administrative investigation if the sending state is unwilling or unable to do so. ${ }^{35}$ This is an important new power for the UN and may help safeguard evidence and establish, at least on a preliminary basis, the relevant facts. In principle, it should ease the way for any criminal investigation the responsible country may choose to undertake. ${ }^{36}$ If the UN investigation is done without sensitivity, however, evidence may be inadvertently tainted or the chain of custody broken, thereby making it more difficult or even impossible for a claim to proceed to trial.

- Vetting candidates. Troop-contributing countries now have an obligation of "vetting candidates for national armies and security forces to ensure the exclusion of those associated with serious violations of international humanitarian and human rights law, including sexual violence." 37 This effort is aimed at ensuring that those with poor records of behavior are not selected for future missions. At present, the UN has little ability to monitor such
Troop-contributing countries are now obliged to report to the UN on the progress and outcome of misconduct investigations and prosecutions.... The 2012 statistics hover around a 50 percent response rate. 
More transparent reporting would provide a better incentive for states to comply with their commitments to investigate and prosecute sexual exploitation and abuse. processes to ensure they meet minimum standards. It is also unclear what it means to be associated with the listed crimes. One assumption is that the phrase 'associated with' is a broader formulation than 'convicted of.' In other words, it is assumed that the proviso is meant to apply not only to individuals convicted of the relevant crimes but also to others somehow affiliated with acts of criminality, regardless of whether they were investigated or prosecuted. This would make sense in light of the difficulties associated with criminal investigations and prosecutions but may be difficult to implement. States that have formal selection processes tend to focus on issues such as hierarchy, rotational demands, and the like. Individuals convicted of offenses are often disbarred from the military or police and thus not eligible. Given the few adequate investigations and prosecutions, the list of individuals who have been convicted is short; reprimands and denials of privileges typically follow proven misconduct. In the absence of a conviction or a negative finding, what other form of proof might deny individuals the privilege of serving in a peacekeeping mission?

In sum, the new model memorandum is a positive step, but a number of gaps remain. The obligation of troop-contributing countries to provide assurances and to share information is an important lever for accountability. However, the failure of the Conduct and Discipline Unit to publish detailed statistics per country and of the secretary-general to publish more revealing summaries in his annual reports is highly unfortunate. More transparent reporting would provide a better incentive for states to comply with their commitments to investigate and prosecute sexual exploitation and abuse. At present, the statistics provide only a veneer of follow-up. Appropriate follow-up would consist of detailed information on the results of investigations, any charges filed, disciplinary procedures and prosecutions, and broader measures of prevention to guarantee nonrecurrence. Further, the memorandum does not clarify or define the crimes that should be subject to investigation and prosecution. Thus the extent to which conduct will be subject to prosecution entirely depends on the applicable criminal law, and standards will vary from country to country.

\section{Host State Role}

In 2005, also in response to the Zeid report, the UN General Assembly's Special Committee on Peacekeeping Operations recommended that a group of legal experts be appointed to advise how best to overcome the remaining legal barriers to criminal accountability of peacekeepers, staff, and experts on mission. ${ }^{38}$ The Group of Experts was formed and issued its report in 2006. The report proposes a number of strategies to end impunity, including the possibility for states to agree to a new convention on the matter. ${ }^{39}$ The Sixth Committee of the General Assembly (the Legal Committee) has retained the item "criminal accountability of United Nations officials and experts on mission" on its annual agenda ever since and continues to discuss the Group of Experts recommendations in that forum..$^{40}$

The Group of Experts report provides a detailed overview of the barriers to accountability and outlined wide-ranging steps to be taken by both the UN and its member states to address such barriers. The principal challenges are extending the jurisdiction to investigate and prosecute and addressing disparities in national criminal law.

\section{Extend Jurisdiction to Investigate and Prosecute}

The report leaves unchallenged the exclusive jurisdiction of the troop-contributing country to investigate and prosecute its military contingents. It suggests a much greater role for the host state in relation to all other categories of personnel (beyond military contingents) and envisions a role for other states to investigate and prosecute as necessary. 


\section{Host State}

One of the main recommendations is to have greater recourse to the host state for investigations and prosecutions of peacekeeping officials, UN staff, and experts on mission. ${ }^{41}$ These categories of personnel have functional immunity - meaning that they cannot be prosecuted or incur civil liability for acts undertaken in the fulfillment of their official functions. The host state would therefore have competence to investigate and prosecute any acts undertaken in a private or unofficial capacity. The recommendation contains two main elements.

Both the Zeid and the Group of Experts reports recommend that functional immunity be waived to allow the host state to investigate and prosecute where appropriate. It has always been the right of the UN secretary-general to waive this immunity; the reports recommend that the secretary-general exercise this discretion much more liberally. Indeed, the Group of Experts report seeks to make the waiver of immunity a priority, given that the host state is where the crimes took place and thus where the witnesses and evidence are to be found; holding the trial in the host state would also have the most concrete impact on the affected victims. However, despite these benefits, the UN is unlikely to waive immunity in order to enable the host state to exercise criminal jurisdiction if its legal system is dysfunctional or if the ability of the local justice system to guarantee fair trials is in doubt. Given that peacekeeping operations are typically operating in a conflict, quasi-conflict, or postconflict context, such concerns are often, if not typically, present.

In light of fair trial concerns, the Group of Experts report also recommends helping the host state exercise criminal jurisdiction through capacity-building initiatives aimed at strengthening its justice system. However, this too seems unrealistic given the need to carry out speedy investigations and preserve evidence and to ensure that trials take place without undue delay. Legal system strengthening is typically a long-term process and is unlikely to bring any major shifts in capacity in the short term, regardless of the intensity of training inputs. The Zeid report proposes encouraging the host state to accept support from the UN to ensure that criminal proceedings against UN personnel satisfy international human rights standards. The Group of Experts points out that this would lead to a separate standard of treatment for international officials but that the concern should not automatically rule out this course of action: "Some accountability may often be better than none for the victims." ${ }^{\text {"12 }}$

The Group of Experts report also points to the possibility of establishing a hybrid tribunal in the host state to include international elements, as was done in Sierra Leone, East Timor, and Cambodia. ${ }^{43}$ This arrangement requires the consent of the host state and is typically resource intensive. However, in instances of widespread sexual exploitation and abuse in particular missions, such as the DRC, it may be appropriate and worth pursuing.

Even when the host state cannot undertake the entire investigation and prosecution, whether for lack of capacity or any other reason, the Group of Experts report also recommends helping the host state provide support or technical assistance to carry out investigations. This action, it argues, would have the benefit of allowing "evidence to be gathered promptly by the host State and transmitted through mutual legal assistance channels to the state undertaking the prosecution. The prompt and effective gathering and preservation of evidence by the host state's investigatory authorities can also facilitate its own conduct of future criminal proceedings when its judicial and other authorities become fully functional." 44 However, the extent to which evidence gathered by a host state or the UN in a preliminary administrative investigation will be admissible in the courts of another state carrying out the prosecution will depend on the laws of the other state. For example, Canada has indicated that under its legal system, using evidence from foreign sources such as UN fact-finding reports would be difficult without the direct involvement of the victims in the process. 45 
Informing the OIOS as soon as possible after allegations are made would facilitate the early determination of whether the host state or any other state may have jurisdiction to prosecute and thereby help ensure that the collection and preservation of evidence complies with the laws of that state. The Zeid report also rightly recommends that

\begin{abstract}
an expert in military law, preferably a prosecutor, from the troop-contributing country concerned should participate as a member of any investigation of members of its contingent. That will ensure that the investigation gathers evidence in a manner that satisfies the requirements of national law so that further action can be taken if it is concluded that misconduct has occurred. ${ }^{46}$
\end{abstract}

\title{
Other States
}

The Group of Experts report recommends that states other than the host state have jurisdiction to investigate and prosecute peacekeeping crimes. It has indicated that the exercise of jurisdiction by other states "should be complementary; that is, to the extent that the host state does not have the capacity to exercise jurisdiction, the greater the need for other states to exercise jurisdiction, the greater the need for other states to do so."47 The report tends to consider the role of troop-contributing countries as subsidiary to the role of the host state. This does not align with the practice that tends to privilege the role of the troop-contributing country over that of the host state, even when the troop-contributing country does not have exclusive jurisdiction to discipline and punish.

The Group of Experts also recommends that states establish universal jurisdiction over peacekeeping crimes, the rationale being that when a crime is carried out in the peacekeeping context, the abuse of power implicit in the crime makes what would normally be an ordinary crime (not normally giving rise to universal jurisdiction) into an international crime that all members of the international community have an interest in prosecuting. 48 This is an important finding that recognizes the special gravity of crimes committed in the peacekeeping context. Because it goes beyond current treaty frameworks for crimes under international law, the Group of Experts report recommends introducing an extradite or prosecute provision into a new proposed treaty to enable states other than the host state to exercise jurisdiction when the host state is not in a position to prosecute. States other than the host state and the troop-contributing country might have an interest to prosecute if an alleged offender is found on their territory. It is less likely, however, that they would request extradition of a suspect if that suspect is not their national and the offense had no direct impact on their citizens. This is certainly the experience of universal jurisdiction prosecutions for crimes already recognized under international law. The vast majority of prosecutions on the basis of universal jurisdiction have concerned individuals found on the territory of the state seeking to exercise jurisdiction or where nationals of the state seeking to prosecute were victims of the crimes. In only a few instances have states sought to extradite individual offenders, even though doing so is permitted in certain treaty frameworks. 49

\section{International Criminal Court}

Extending the jurisdiction of the International Criminal Court (ICC) to specifically cover peacekeeping abuses would be difficult given that many of the top troop-contributing countriessuch as India, Pakistan, Nepal, Ethiopia, Rwanda, and Egypt-are not states parties of the court. Furthermore, the crimes over which the court has jurisdiction are presently limited to genocide, crimes against humanity, and war crimes. It is certainly arguable that sexual exploitation and abuse by peacekeepers may, in limited circumstances, fall within the definition of crimes against humanity or war crimes, but it is unlikely that the Office of the Prosecutor 
would emphasize individual peacekeepers' acts of sexual exploitation and abuse unless carried out on a widespread and systematic basis and thus already arguably a crime against humanity. Extending ICC jurisdiction without this link to crimes against humanity is also likely to overwhelm a court that is already overstretched and significantly underresourced.

\section{New Special Court}

A new special court could be established to exercise jurisdiction over crimes committed within the peacekeeping context if the troop-contributing country is unable or unwilling to investigate or prosecute. This structure would be similar to the complementarity provisions of the ICC. It could be achieved by treaty, though effectiveness would then depend on which states decided to ratify the treaty, unless ratification were a precondition to accepting troops from any country. Such a precondition might dissuade many countries from participating in new missions. However, according to the Group of Experts report, for many categories of peacekeeping personnel, the number of persons available or made available for consideration by the UN often exceeds the number of posts. ${ }^{50}$ Involvement in peacekeeping missions can be lucrative for certain states. Thus it is not clear that in all cases a precondition would act as a form of dissuasion. Demand may not always outstrip supply. However, given that relatively few countries supply the vast majority of troops, it would be important that these countries express their commitment to such an approach.

A special court could also be established by resolution of the UN Security Council under Chapter VII. Presumably this would not be an ad hoc court to deal with past instances of criminality, such as the International Criminal Tribunal for Rwanda or for the former Yugoslavia, where the link to maintaining or restoring international peace and security was perhaps more evident. Here we are concerned with a forward-looking institution, potentially with a permanent structure. It is highly unlikely that such a structure would be acceptable to permanent Security Council members, however.

\section{Address Disparities in Domestic Criminal Law}

The standards of conduct set out in the 2003 bulletin on special measures for protection from sexual exploitation and sexual abuse now apply to all categories of peacekeeping personnel, whether military contingents, police observers, UN personnel, or volunteers. 51 This is an important sign of progress. However, not all acts of sexual exploitation and abuse amount to criminal conduct. The 2003 bulletin and other UN disciplinary codes on the subject outlaw a wide range of conduct but do not distinguish between acts that may constitute criminal offenses and acts that may result in disciplinary action only.

Some of the most typical forms of sexual exploitation and abuse that peacekeepers are known to have engaged in are not explicitly reflected in international humanitarian law treaties. No uniform coverage of such conduct therefore exists in domestic criminal law statutes. For instance, not all troop-contributing countries will have either the same minimum age of consent for sexual relations or the same approach to prostitution. Sexual exploitation of women and young persons is not uniformly recognized as a crime by troop-contributing countries. When peacekeepers - the persons sent by the international community to protect the civilian population-engage in this behavior in a conflict or postconflict context, the dynamics change, and gravity is added. The additional gravity arguably warrants the criminalization of conduct that otherwise might amount only to a breach of discipline. The criminal codes of troop-contributing countries and host states vary in terms of what constitutes a criminal offense under domestic law, the breadth of the criminal offenses that can be prosecuted when they take place outside the territory of the troop-contributing country (extraterritorially), and the seriousness attributed to such offenses and the applicable punishments.
Some of the most typical forms of sexual exploitation and abuse ... are not explicitly reflected in international humanitarian law treaties. Sexual exploitation of women and young persons is not uniformly recognized as a crime by troop-contributing countries. 
Given the nature of military operations, military criminal law regularly extends to the acts of serving military wherever they might be operating. The state of nationality can hold a court-martial for the offending soldier for any act that contravenes the applicable law. The same is not true for police or civilian experts serving in or supporting peacekeeping operations, to whom military law would not usually apply. In the latter cases, ordinary criminal law applies. Such law is primarily territorial-that is, it does not apply to acts that take place outside the country, a few specific enumerated exceptions aside. Sexual violence and exploitation are not typically recognized as exceptions. For instance, under Canadian law, the limited exceptions that allow for extraterritorial jurisdiction focus on when an international legal obligation to prosecute exists or a prosecution relates to fulfilling Canada's essential interests: “Canada would extend jurisdiction over crimes committed by Canadian nationals while serving as United Nations officials or experts on mission only when they fall within one of those exceptions." 52 American law is similarly limited. At present, it is only possible to prosecute the felony offenses of civilian employees, contractors, and contract employees of the Department of Defense and other federal agencies to the extent that their employment relates to supporting the mission of the Department of Defense overseas.53 The law does not extend to civilians working in support of the mission of other agencies. This gap gained notoriety when Dyncorp contractors allegedly linked to trafficking rings in Bosnia and Herzegovina could not be criminally prosecuted in the United States. Efforts to close the remaining gaps in the law have thus far been unsuccessful. 54

Whether conduct will be subject to criminal proceedings will depend on the legal framework of the state seeking to exercise jurisdiction. The offensive conduct will therefore lead to different results, depending on local laws and how they are applied. Complicating matters further, some troop-contributing countries prosecute only if the conduct constitutes a comparable crime in the host state, thus making prosecutions contingent on the legislation of countries with fragile legal systems emerging from conflict.

These disparities in criminal law lead to at least two problems. First, it is difficult for clarity and transparency as well as for morale when conduct outlawed in codes of conduct applicable to all troops and related personnel of a peacekeeping mission leads only to the possibility of criminal sanctions for soldiers coming from a limited number of countries. Accountability standards should be applied across the board. Second, an ill-fitting domestic criminal law framework for peacekeeping abuses may result in prosecutors trying to fit the misconduct they are confronted with into other well-established crimes, even when the facts clearly do not match; this process can ultimately result in judicial rejection of charges. This situation was particularly prominent in Somalia missions: Prosecutions for several notorious instances of torture failed because directly relevant criminal offenses were not in the statute books of troop-contributing countries.

\section{Draft a New Convention?}

A central recommendation of the 2006 Group of Experts report was to develop a new international convention to regulate the criminal liability of peacekeepers. ${ }^{55}$ The convention would signify the importance attached by the international community to such crimes, which "cannot, in view of the circumstances in which they were committed, be regarded merely as ordinary crimes." 56 It could also ensure greater consistency in the criminalization of conduct. It could address issues such as the different bases for states to exercise jurisdiction over the criminal conduct of peacekeepers, whether as the host state where the crimes took place, the troop-contributing country, or any other state that could step in when the former state does not act-a form of a subsidiary "prosecute or extradite" clause. As indicated earlier, a new convention is arguably required to recognize what 
would normally be considered an ordinary crime as a crime under international law meriting universal jurisdiction. The convention could also facilitate the exchange of information and evidence between states and between the UN and states, as well as ease cross-jurisdictional investigations.

Arguably, some issues could be addressed in ways other than a new convention: by the troop-contributing countries through revisions of their laws and criminal procedures, or by changes to the memorandum of understanding. ${ }^{57}$ Such ad hoc approaches, however, cannot resolve other issues, such as extending extraterritorial criminal jurisdiction for states, harmonizing criminal law standards relating to peacekeeping offenses, strengthening mutual legal assistance, recognizing evidence by foreign sources, and potentially more smoothly regulating jurisdiction between the host state, troop-contributing countries, and other states.

Support for a new convention has been mixed. All states that have commented on the text recognize the need to counteract impunity for peacekeeping abuses and that immunities and other procedural barriers should not impede criminal prosecutions: "A zero-tolerance policy with regard to sexual abuse and other criminal acts should remain the guiding principle." ${ }^{\prime 58}$ Countries that contribute significant troops and related personnel to peacekeeping missions, such as Nigeria and Bangladesh, have expressed their commitment to the principle of accountability, though they have made no direct reference to the proposed convention. ${ }^{59}$ Countries such as Congo, the DRC, Canada, Australia, and New Zealand, as well as the European Union have spoken in favor of a new convention. ${ }^{60}$ The UN Secretariat has as well. ${ }^{61}$ India and the United States, however, have indicated that they are not convinced that a multilateral convention is the most effective way to ensure accountability. ${ }^{62}$ 0ther countries-such as Israel, El Salvador, the Russian Federation, and Ukraine-have suggested more useful starting points. That is, consideration of a convention is premature. 63

In a series of successive General Assembly resolutions, states have been encouraged to plug the gaps, by-among other ways-establishing jurisdiction over serious crimes committed by their nationals while serving as UN officials or experts on mission, cooperating with each other and with the UN in exchanging information, and facilitating the conduct of investigations and prosecutions. ${ }^{64}$ These resolutions are important in drawing attention to the need to address the issue of criminal accountability. However, the resolutions are not in and of themselves binding obligations, and thus far, from the record over the past eight years since the annual resolutions have begun to be adopted, no evidence indicates that they have led to greater accountability. The Sixth Committee of the United Nations continues to collate information on the extent to which national laws allow for investigations and prosecutions. Responses have varied. Quite a number of states have given very generalized statements as to the adequacy of their internal legislation. Few have highlighted areas where gaps may exist. The secretary-general has collated much of this data in annual reports yet without any independent analysis. The sense that emerges is thus somewhat contradictory: The vast majority of allegations have not resulted in prosecutions, yet states' procedural and substantive legislation seems, on the basis of what the states are reporting, free from significant gaps.

The pattern of lukewarm reporting and cut-and-paste General Assembly resolutions has continued since 1996. New allegations continue to emerge and be added to a growing list of allegations that have not resulted in criminal accountability.

\section{Recommendations}

The UN and its independent experts have undertaken critical work in identifying the problems related to ensuring accountability among peacekeepers. Now that the gaps are known, more sensitive and targeted work is needed to finish the job. 


\section{The UN should acknowledge itself as having an active and persistent role in helping states close the gaps in disciplinary and criminal accountability.}

The UN, however, does not appear to see pressing states further in this direction as its role. It is the ultimate responsibility of states to ensure that those sent on peacekeeping missions are capable of meeting the highest standards, to discipline their peacekeeping personnel and ensure criminal accountability, to come together to agree on a new convention, and to amend domestic laws to cover jurisdiction over troop contingents on peacekeeping missions.

For UN-mandated operations, however, the UN bears institutional responsibilty for acts and omissions that take place within the mission context. Numerous courts have recognized this. ${ }^{65}$ The responsibility requires more than a laissez-faire approach: The UN should acknowledge itself as having an active and persistent role in helping states close the gaps in disciplinary and criminal accountability, even if it is not for the UN to discipline and punish.

Much greater use of the UN's tools under the new memorandum is in order and straightforward:

- Naming and shaming states that fail to investigate and prosecute. The concept is neither new nor novel. It is in fact the basis on which much of the UN Human Rights Council and its special procedures operates.

- Actively working with states to bridge gaps in domestic legislation. This would include issuing written advice, publishing model legislation, and engaging directly with states. The UN has extensive experience in providing support and technical assistance to states to strengthen the rule of law and enshrine human rights.

- Refraining from accepting troop contingents from countries that repeatedly fail to live up to written assurances to investigate and prosecute. This discipline will require an attitudinal change within the Department of Peacekeeping Operations: developing an arm'slength distance from the states that supply troops. Presently, the department's seeming inability to do so affects both its credibility and its ability to carry out its mandate. Decisions on conditioning the acceptance of troop contingents should be taken by more neutral agencies, such as a dedicated team within the Office of the High Commissioner for Human Rights.

The memorandum might also be further revised to introduce greater conditionality into the acceptance and removal of troop contingents.

Troop-contributing countries are slow to investigate and reluctant to prosecute alleged offenders for a variety of reasons. Weak legislation and poor investigations capacity are technical issues that can be addressed through relevant reforms. However, in addition, peacekeeping is a source of pride for troop-contributing countries. None wish to draw attention to any stain of abuse. This is natural and underscores the importance of the UN's publicizing more concrete information about abuse allegations. The UN, however, does not wish the allegations to be made public either: Abuse allegations that affect troop-contributing countries also affect the UN. Transparent reporting thus carries a double disincentive.

The instances of sexual exploitation and abuse that have come to light have mainly been reported by whistleblowers, NGOs, or humanitarian agencies, not by complaint structures or the UN. If publication were more transparent, troop-contributing countries would have a greater incentive to undertake full and complete investigations and prosecutions, and the UN would have a stronger incentive to maintain the pressure.

Lack of interest in accountability also stems from the allegations themselves. A sense prevalent in many militaries around the world is that boys will be boys, that allowances should be made for peacekeepers who are far from their families, and that these kinds of abuses are natural and inevitable. Such stereotypical attitudes are slowly being addressed on the preven- 
tion side by training and awareness programs before and after deployment and more explicit codes of conduct. They will only take hold, however, if they are accompanied by strong policies of enforcement when abuse allegations emerge. This was the clear message of the G8 ministers in their April 2013 Declaration on Preventing Sexual Violence in Conflict, when they affirmed that "more must be done to address these ongoing crimes, including by challenging the myths that sexual violence in armed conflict is a cultural phenomenon or an inevitable consequence of war or a lesser crime." It would be an anathema for so much rhetoric to be expended on countering the abhorrent practice of sexual violence in conflict without simultaneously taking the clear steps identified since 2006 to tackle the persistent problem of sexual exploitation and abuse by peacekeepers. The two challenges go hand in hand.

A clearer roadmap to a new convention might be prepared under the auspices of the UN General Assembly's Special Committee on Peacekeeping Operations, identifying annual targets to foster progress. The resolutions are an important starting point in identifying applicable principles. They could be developed into a more precise set of principles for troop-contributing countries to be signed off before UN acceptance of their troops. The committee could also coordinate with the Human Rights Council to appoint an independent expert to carry out audits on each existing and prospective troop-contributing country: essentially an independent scorecard on compliance. Such audits could be compulsory, made public, and considered by the Special Committee on Peacekeeping Operations. Bad scorecards without annual improvements should lead to the suspension of contributions from the particular state. One worry is that the greater regulation might be avoided if states circumvent the regulation by doing more peacekeeping either through other multilateral institutions, such as the African Union and the North Atlantic Treaty Organization, or through informal state coalitions. This is already happening, though perhaps for other reasons. It is therefore important to draw in the main regional, subregional, and other actors into discussions on how best to regulate criminal accountability so that effective across-theboard solutions can be found.

\section{It would be an anathema for so much rhetoric to be expended on countering the abhorrent practice of sexual violence in conflict without simultaneously taking clear steps ... to tackle the persistent problem of sexual exploitation and abuse by peacekeepers.}




\section{Notes}

1. Chiyuki Aoi, Cedric de Coning, and Ramesh Thakur, eds., Unintended Consequences of Peacekeeping Operations (New York: United Nations University Press, 2007).

2. "Statistics do not illustrate the damage that criminal activity of all kind causes the reputation of every peacekeeper and the United Nations Organization as a whole. Statistics do not show how criminal conduct impacts on the fulfilment of the mandate and the success of a United Nations operation, as well as the threat to the physical security of United Nations personnel. Whenever crimes are committed by persons participating in a United Nations operation, there will be an impact on the trust that the United Nations seeks from the local community. This breach of trust makes the work of the United Nations difficult to accomplish. Without the trust of the community, mandates will not receive full cooperation and may fail or take longer to achieve." UN General Assembly (UNGA), "Criminal accountability of United Nations officials and experts on mission," Note by the Secretariat, A/62/329, September 11, 2007, paras 11-12.

3. This is underscored in the 2013 Declaration on Preventing Sexual Violence in Conflict, adopted by G8 foreign ministers in London on April 11, 2013: "Sexual violence in armed conflict represents one of the most serious forms of violation or abuse of international humanitarian law and international human rights law. Preventing sexual violence in armed conflict is therefore both a matter of upholding universal human rights and of maintaining international security, in keeping with UN Security Council Resolution 1820. Ministers emphasised that more must be done to address these ongoing crimes, including by challenging the myths that sexual violence in armed conflict is a cultural phenomenon or an inevitable consequence of war or a lesser crime."

4. UN Security Council Resolution S/RES/2106 of June 24, 2013.

5. Agreements with troop-contributing countries stipulate that these sending countries-not the UN or the countries where the troops are stationed-are solely responsible for disciplining and punishing troop contingents. The International Criminal Court or ad hoc international criminal tribunals may have jurisdiction over certain crimes relating to peacekeepers; however, whatever limited jurisdiction may exist will not apply equally to all peacekeeping contingents or to all relevant crimes. Investigation and prosecution by such international courts and tribunals cannot therefore be relied on as an adequate or exhaustive response.

6. Office of Internal Oversight Services (OIOS), "Activities of the Office of Internal Oversight Senvices on peacekeeping operations for the period from 1 January to 31 December 2012," A/67/297 (part II), March 12, 2013.

7. For instance, the widely reported allegations of sexual exploitation of refugees by aid workers in West Africa (OIOS "Investigation into sexual exploitation of refugees by aid workers in West Africa," A/57/465, October 11, 2002); abuses involving the peacekeeping mission in the Democratic Republic of the Congo (OIOS, "Investigation by the Office of Internal Oversight Services into allegations of sexual exploitation and abuse in the UN Mission in the Democratic Republic of the Congo," A/59/661, January 5, 2005); and the revelations of peacekeepers' involvement in trafficking rings and in the solicitation of trafficked women in Bosnia and Herzegovina.

8. Corinna Csáky, "No One to Turn To: The under-reporting of child sexual exploitation and abuse by aid workers and peacekeepers," Save the Children UK, 2008.

9. UN Secretary-General, "Special measures for protection from sexual exploitation and sexual abuse," A/67/766, February 28, 2013.

10. Prince Zeid Ra'ad Zeid Al-Hussein, "A comprehensive strategy to eliminate future sexual exploitation and abuse in United Nations peacekeeping operations," A/59/710, March 24, 2005.

11. UN Secretary-General, "Bulletin on special measures for protection from sexual exploitation and sexual abuse," ST/SGB/2003/13, October 9, 2003. This bulletin was adopted before the Zeid report but was subsequently made applicable to all categories of UN peacekeeping personnel, including military contingents. See UN General Assembly, "Report of the Special Committee on Peacekeeping Operations and its Working Group, 2005 resumed session," April 4-8, 2005, A/59/19/Rev.1, chap II, para 8, which was specifically endorsed in UN General Assembly Resolution 59/300, June 30, 2005.

12. UNGA, "Report of the Special Committee on Peacekeeping Operations and its working group on the 2007 resumed session," A/61/19 (part III), annex, June 12, 2007.

13. The Executive Committees on Humanitarian Affairs and Peace and Security (ECHA/ECPS) United Nations and Nongovernmental Organization Task Force on Protection from Sexual Exploitation and Abuse was established in February 2005 with the aim of preventing acts of sexual exploitation and abuse and improving the response to it when it occurs.

14. UNGA, "Comprehensive strategy on assistance and support to victims of sexual exploitation and abuse by United Nations staff and related personnel," A/RES/62/214, March 8, 2008.

15. UN Secretary-General, "Comprehensive report prepared pursuant to General Assembly Resolution 59/296 on sexual exploitation and sexual abuse, including policy development, implementation and full justification of proposed capacity on personnel conduct issues," A/60/862, May 24, 2006. See also UN Secretary-General, "Special measures for protection from sexual exploitation and sexual abuse," A/63/720, February 17, 2009.

16. In November 2005, a special team was established, later named the Conduct and Discipline Unit (CDU). It is part of the Department of Field Support and is mandated to provide oversight and to carry out investigations into allegations of misconduct. Serious offenses are referred to the OIOS, which is then responsible for investigating.

17. See, for example, Xabier Agirre Aranburu, "Sexual Violence Beyond Reasonable Doubt: Using Pattern Evidence and Analysis for International Cases," Law \& Social Inquiry 35, no. 4 (2010): 855.

18. UNGA, "Model status-of-forces-agreement for peacekeeping operations," report of the Secretary General, A/45/594, October 9, 1990.

19. The different categories and status of persons on missions is described in UN Commission on Human Rights (UNCHR), "Working paper on the accountability of international personnel taking part in peace support operations submitted by Françoise Hampson," E/CN.4/Sub.2/2005/42, July 7, 2005.

20. The prosecution of crimes that took place outside the country where the prosecution is being held.

21. UNCHR, "Working paper on the accountability of international personnel," (n 19), paras 39-45, 64.

22. See UN Conduct and Discipline Unit, "Statistics: UN Follow-up with Member States (Sexual Exploitation and Abuse)", 2010, http://cdu.unlb.org/Statistics/UNFollowupwithMemberStatesSexualExploitationandAbuse.aspx Emblematic case summaries are provided in the annual reports of the OIOS. However, these too do not mention the name of the troop contributing countries, making the independent follow up of any criminal investigations 
and prosecutions carried out by that country difficult. Follow-up by a troop contributing country can have a variety of meanings. For instance, the 0IOS annual report on March 12, 2013, summarizes ID case 0405/11: “It was reported that a national contingent member in MONUSCO had attempted to sexually abuse a casual worker of a United Nations programme. It was further reported that the same national contingent member had earlier that same day attempted to sexually assault another casual worker of the same United Nations programme. The concerned troop-contributing country was notified of the report in accordance with the provisions of the revised draft model memorandum of understanding, and a National Investigations Officer was subsequently appointed. The Organization has not yet received the troop-contributing country's investigation report. However, in an official response, the troop-contributing country referred to only one victim and reported that she had withdrawn her complaint against the national contingent member. In contrast to that, OIOS has no evidence that the complaint had been withdrawn and recommended further investigation by the troop-contributing country. On 28 March 2012, 0IOS provided its report to the Department of Field Support. On 21 May 2012, the Department transmitted the findings to the troop-contributing country; to date, however, no response has been received from the troop-contributing country" ("Activities of the Office of Internal Oversight Services," A/67/297 (part II), paras 58-59).

23. Center for Economic and Policy Research, "MINUSTAH Officers Found Guilty of Rape-But Get Just One Year in Prison," March 13, 2012, www.cepr.net/.

24. Steve Stecklow, “U.N. Peacekeepers Dodge Discipline," Wall Street Joumal, March 22, 2010, http://online.wsj.com.

25. See Gerald Caplan, "Peacekeepers gone wild: How much more abuse will the UN ignore in Congo?" Globe and Mail, August 3, 2012, www.theglobeandmail.com/news/politics/second-reading/peacekeepers-gone-wild-howmuch-more-abuse-will-the-un-ignore-in-congo/article4462151; Varinder Bhatia, "Indian Army probes reports of its UN peacekeepers fathering kids in Congo," June 7, 2011, www.indianexpress.com/news/indian-army-probesreports-of-its-un-peacekeepers-fathering-kids-in-congo/800244/1; Manu Pubby, "Ensure maximum punishment to errant troops: Ban to India," The Indian Express, August 14, 2008, www.indianexpress.com/news/ensuremaximum-punishment-to-errant-troops-ban-to-india/348664/0.

26. Center for Economic and Policy Research, "Reduced charges against Uruguayan MINUSTAH troops latest example of lack of UN accountability," September 4, 2012, www.cepr.net/.

27. UNGA, "Report of the Special Committee," A/61/19, 2007.

28. Ibid., article 7 , quinquiens.

29. Ibid., article 6 , sexiens, para 1 .

30. Ibid.

31. UNCHR, "Working paper on the accountability of international personnel," (n 19) paras 65, 66.

32. See UNGA, "Report of the Special Committee," A/61/19 (part III), annex, article 7ter, 7quater, 7quinquiens, 7sexiens.

33. The statistics are available on the website of the Conduct and Discipline Unit: http://cdu.unlb.org/Statistics/ UNFollowupwithMemberStatesSexualExploitationandAbuse.aspx.

34. Ibid.; UNGA, "Report of the Special Committee," A/61/19, article 7, quater, para 2.

35. UNGA, "Report of the Special Committee," A/61/19, article 7, quater, para 3(a).

36. The UN Secretariat has repeatedly made this point. See UNGA, "Criminal accountability," A/62/329, 2007, paras 44, 50, 51.

37. UN Security Council Resolution 1888, September 30, 2009, para 3.

38. UNGA, "Report of the Special Committee," A/59/19/Rev.1, 2005.

39. UNGA, "Report of the group of legal experts on ensuring the accountability of United Nations staff and experts on mission with respect to criminal acts committed in peacekeeping operations," A/60/980, August 16, 2006.

40. See, for example, UNGA, "Criminal accountability of United Nations officials and experts on mission," A/ RES/67/88, January 12, 2013.

41. UNGA, "Report of the group of legal experts," A/60/980, paras 27, 44.

42. Ibid., para 30 .

43. Ibid., paras 33-37.

44. Ibid., para 79 .

45. UNGA, "Situation of human rights in the Democratic People's Republic of Korea," A/66/174, July 25, 2011, para 35.

46. Zeid, "A comprehensive strategy," para 33.

47. Ibid., para 44(a).

48. Ibid., paras 55-58.

49. A possible exception is Belgium's extradition request to Senegal to prosecute former Chadian President Hissène Habré.

50. UNGA, "Report of the group of legal experts," para 65(b).

51. UN Secretary-General, "Special measures for protection from sexual exploitation and sexual abuse," ST/ SGB/2003/13, October 9, 2003.

52. UNGA, "Criminal accountability of United Nations officials and experts on mission," Report of the secretarygeneral, A/63/260, August 11, 2008, para 12.

53. MEJA (the Military Extraterritorial Jurisdiction Act of 2000, 18 USC $\S 3261$ et seq.), as amended in 2005, applies to felony-level offenses committed by persons employed by or accompanying the armed forces outside the United States.

54. Attempts to amend the federal criminal code to grant jurisdiction over and impose penalties on federal contractors and employees who commit certain crimes outside the United States while employed by or accompanying any agency of the United States other than the Department of Defense (DOD) have thus far failed. See U.S. Congress, Civilian Extraterritorial Jurisdiction Act (CEJA) of 2011, S. 1145, 112th Congress.

55. UNGA, "Report of the group of legal experts," A/60/980, para 63. 
eISBN: 978-1-60127-188-4

An online edition of this and related reports can be found on our Web site (www.usip.org), together with additional information on the subject.
56. Ibid., para 63(e).

57. UNGA, "Criminal accountability," A/62/329, 2007, paras 24-25.

58. UNGA, "Summary record of the 9th meeting," A/C.6/67/SR.9, December 20, 2012.

59. Ibid.

60. UNGA, "Summary record of the 8th meeting," A/C.6/67/SR.8, December 5, 2012.

61. UNGA, "Criminal accountability," A/62/329, 2007.

62. UNGA, "Summary record of the 8th meeting," A/C.6/67/SR.8; "Summary record of the 9th meeting," A/C.6/67/SR.9, para 7 .

63. UNGA, "Summary record of the 9th meeting," A/C.6/67/SR.9; "Summary record of the 8th meeting," A/C.6/67/SR.8.

64. See, for example, UNGA, "Criminal accountability," A/RES/67/88, January 14, 2013.

65. See, for example, Behrami and Behrami v France; Saramati v France, Germany and Norway (2007), 45 European Human Rights Reports 10.

\section{Of Related Interest}

- Wartime Sexual Violence: Misconceptions, Implications, and Ways Forward by Dara Kay Cohen, Amelia Hoover Green, and Elisabeth Jean Wood (Special Report, February 2013)

- Women and War: Power and Protection in the 21st Century edited by Kathleen Kuehnast, Chantal de Jonge Oudraat, and Helga Hernes (USIP Press, 2011)

- Sexual Violence and Justice in Postconflict Peru by Jelke Boesten and Melissa Fisher (Special Report, June 2012)

- Gender and Statebuilding in South Sudan by Nada Mustafa Ali (Special Report, December 2011)

- The Other Side of Gender: Including Masculinity Concems in Conflict and Peacebuilding by Kathleen Kuehnast and Nina Sudhakar (Peace Brief, January 2011)

- Security after the Quake? Addressing Violence and Rape in Haiti by Brooke Stedman (Peace Brief, January 2011)

- Gender, Conflict, and Peacebuilding by Kimberly Theidon and Kelly Phenice with Elizabeth Murray (Peaceworks, September 2011)

- The Role of Women in Global Security by Valerie Nonille (Special Report, December 2010)

- Rape in War: Motives of Militia in DRC by Jocelyn Kelly (Special Report, May 2010) 